\title{
KAJIAN META- ANALISIS INOVASI PENGAJARAN USUL FIQH DI INDONESIA
}

\author{
*Faisal Bin Husen Ismail', Arwansyah Bin Kirin², Che adenan Bin Mohammad", \\ Abd Shakor Bin Borham ${ }^{4}$, Muhammad Masruri ${ }^{5}$ \\ Pusat Pengajian Umum dan Ko-Kurikulum \\ Jabatan Pengajian Islam \\ Universiti Tun Hussein Onn, Malaysia \\ *faisalhu@uthm.edu.my
}

\section{Abstrak:}

Kajian berkaitan usul fiqh berkembang pesat di seluruh dunia Islam termasuk di Indonesia. Oleh yang demikian ada keperluan untuk menganalisis kajian-kajian sebelumnya untuk mengetahui bentuk dan kecenderungan kajian yang telah dijalankan. Objektif kajian adalah untuk mengetahui corak dan jurang penyelidikan yang telah dilakukan pengkaji sebelumnya. Metode Kualitatif digunakan dalam kajian ini dengan menganalisis artikel-artikel kajian lepas secara sistematik berkaitan inovasi pengajaran usul figh di Indonesia tahun 2009 hingga 2018. Kajian ini mendapati sebahagian besar daripada kajian-kajian yang telah dijalankan memberi fokus kepada keperluan pembaharuan ilmu usul figh di Indonesia. Selain itu, hasil kajian juga mendapati pendekatan menggunakan metode kualitatif paling kerap digunakan dimana kajian lapangan adalah metode yang paling disukai. Temuan daripada kajian ini dapat dijadikan rujukan kepada pengkajian berkaitan inovasi pengajaran usul fiqh di Indonesia. Kajian ini juga mencadangkan kajian lebih jauh berkaitan inovasi pengajaran usul fiqh.

Kata Kunci: Inovasi, pengajaran usul figh, pengetahuan ilmu usul fiqh, Indonesia, meta-analisis. 


\section{Abstract:}

Studies related jurisprudence growing rapidly around the Muslim world, including Indonesia. Hence there is need to analyze previous studies on inovation teaching jurisprudence that has been undertaken to identified pattern and disposition of the research conducted. The objective of this study was to determine the pattern and research gaps exist in the field that have been done earlier researchers. Qualitative methods were used in this study. The study systematically analysed articles related innovation in teaching jurisprudence in Indonesia from 2009 to 2018. The findings from the analysis show most of the studies that have been conducted focusing on the need to reform of jurisprudence in Indonesia. Therefore, analysis showed that the approach using qualitative methods most often used where the field study is the most preferred method. The findings of this study can be used as a reference to the study of jurisprudence related to teaching innovation in Indonesia. This article provides suggestions for further research related to innovation in teaching jurisprudence.

Keyword: Innovation, teaching jurisprudence, knowledge of jurisprudence, Indonesia, Meta-Analysis.

\section{Pendahuluan}

Kefahaman teks-teks sumber undang-undang Islam telah dapat difahami dengan lebih mudah melalui kewujudan ilmu usul figh. Melalui ilmu usul figh penentuan hukum menjadi lebih tepat. Disamping itu penghujahan usul figh merujuk kepada alQuran dan Sunnah sebagai sumber utama undang-undang Islam. Umat Islam berhutang budi kepada para ulama silam seperti imam Syafi i yang dianggap sebagai pengasas ilmu usul fiqh1. Proses ijtihad yang telah mereka lakukan mengakibatkan pencapaian Islam dari sudut pengaruh ilmu Islam dapat diaplikasikan dalam semua urusan kehidupan seperti ibadah, ekonomi, muamalah bahkan mencakup urusan pentadbiran negara ${ }^{2}$. Walau bagaimanapun, doktrin klasik yang telah menutup pintu proses ijtihad mengakibatkan kefahaman ke atas ilmu usul figh sebagai ilmu klasik yang sukar untuk dipelajari serta sukar untuk diajarkan. Celakanya lagi, ilmu usul fiqh dianggap sebagai khazanah ilmu Islam yang terpisahkan daripada ilmu fekah yang

\footnotetext{
${ }_{1}$ Abdul Karim, M. A. (2013). Pola Pemikiran Imam Syafi'i dalam Menetapkan Hukum Islam. Jurnal Adabiyah Vol. XIII nomor, 187.

${ }^{2}$ Qutb, S. M. (1992). Petunjuk Sepanjang Jalan. Kuala Lumpur: Crescent News Sdn. Bhd.
} 
umumnya banyak diajarkan dengan pelbagai usaha untuk mempelbagaikan inovasi dalam pengajarannya. Namun, jika diselidik lebih jauh, keperluan kepada inovasi pembelajaran dan pengajaran ilmu usul figh lebih memerlukan perhatian daripada pendidik dalam usaha memartabat kembali asas penting pengamalan ilmu usul figh pada zaman kekinian.

Ulama dan Guru memainkan peranan utama dan strategik dalam mewujudkan kejayaan kepada kefahaman ilmu usul figh dan seterusnya membawa kepada menyumbang pengajaran berkualiti pembelajaran murid ${ }^{3}$ serta dapat menyebarkan maksud agama Islam sebagai rahmatan lil 'alamin ${ }^{4}$. Pengajaran berkualiti memainkan peranan penting bagi mempengaruhi pencapaian murid sebagaimana kajian-kajian yang telah dilakukan ${ }^{5}$. Menurut Baumert et al. (2010) pengetahuan guru dan amalan dalam kelas turut menjadi faktor kepada tahap pencapaian kefahaman murid ${ }^{6}$. Begitu juga jenis latihan guru dan pengalaman turut mempengaruhi faktor kejayaan murid?

Proses pengajaran dan pembelajaran (P\&P) sangat mempengaruhi penguasaan pengetahuan serta pemahaman bagi membolehkan murid mengaplikasikan konsep, prinsip dan proses pengaplikasian ${ }^{8}$ usul fiqh yang dipelajari.

\footnotetext{
3 Kunter, M., Klusmann, U., Baumert, J., Richter, D., Voss, T., \& Hachfeld, A. (2013). Professional competence of teachers: Effects on instructional quality and student development. Journal of Educational Psychology, 105(3), 805.

4 llyas, H. H., \& Ag, M. (2018). Fikih Akbar: Prinsip-Prinsip Teologis Islam Rahmatan Lil 'Alamin: Pustaka Alvabet.

${ }^{5}$ Fung, D., Kutnick, P., Mok, I., Leung, F., Lee, B. P.-Y., Mai, Y. Y., \& Tyler, M. T. (2017). Relationships between teachers' background, their subject knowledge and pedagogic efficacy, and pupil achievement in primary school mathematics in Hong Kong: An indicative study. International Journal of Educational Research, 81, 119-130; Luetz, J. M., Margus, R., \& Prickett, B. (2019). Human Behavior Change for Sustainable Development: Perspectives Informed by Psychology and Neuroscience. In W. Leal Filho, A. M. Azul, L. Brandli, P. G. Özuyar, \& T. Wall (Eds.), Quality Education (pp. 1-16).

${ }^{6}$ Baumert, J., Kunter, M., Blum, W., Brunner, M., Voss, T., Jordan, A., .. . Tsai, Y.-M. (2010). Teachers' mathematical knowledge, cognitive activation in the classroom, and student progress. American educational research journal, 47(1), 133-180.

7 Johari, K., Ismail, Z., Osman, S., \& Othman, A. T. (2009). Pengaruh Jenis Latihan Guru dan Pengalaman Mengajar Terhadap Efikasi Guru Sekolah Menengah (The Influence of Teacher Training and Teaching Experience on Secondary School Teacher Efficacy). Jurnal Pendidikan Malaysia (Malaysian Journal of Education), 34(2), 3-14.

8 Suartama, I. K. (2010). Pengembangan mutimedia untuk meningkatkan kualitas pembelajaran pada mata kuliah media pembelajaran. Jurnal Pendidikan dan Pengajaran, 43(3).
} 
Keberkesanan ke atas pembelajaran juga memerlukan kepada guru yang mengetahui "more and difference" daripada ilmu yang diajarkan seperti pengetahuan bagi menganalisis kesilapan, menerima strategi analisis alternative yang sah serta pemahaman konsep ${ }^{9}$ istinbath.

Secara konsepnya ilmu yang diajarkan amat berkaitan rapat dengan pengetahuan seorang pengajar berkaitan pedagogikal kandungan ilmu yang diajarkan. Menurut Segall $(2004)^{10}$ sebagaimana yang dikutip daripada Gudmundsdottir and Shulman (1987) ${ }^{11}$ yang memperkenalkan "a missing paradigm". Beliau mengkritik kurangnya perhatian yang diberikan terhadap kandungan pelajaran berkaitan latihan mengajar dan penilaian terhadap guru serta kajian berkaitan keberkesanan pengajaran dan latihan mengajar. Berkaitan dengan usul fiqh, konsep pengetahuan dan pedagogikal ke atas ilmu usul fiqh untuk pengajaran bagi menjelaskan pengetahuan yang perlu dikuasai oleh seorang guru perlulah diberi tumpuan oleh para pengkaji. ${ }^{12}$ Namun demikian, dalam konteks kajian berkaitan pengamalan ilmu usul figh di Indonesia, ianya adalah kurang jelas. Justeru terdapat keperluan untuk menganalisis kajian-kajian terdahulu berkaitan pengajaran guru yang telah dijalankan di Indonesia bagi mengenalpasti corak dan dan jurang kajian yang wujud.

Kajian ini dijalankan bagi menjawab persoalan kajian berikut:

\footnotetext{
${ }_{9}^{9}$ Kilpatrick, J., Swafford, J., \& Findel, G. (2001). Teaching for mathematical proficiency. Adding it up: Helping children learn mathematics, 313-368.

10 Segall, A. (2004). Revisiting pedagogical content knowledge: the pedagogy of content/the content of pedagogy. Teaching and teacher education, 20(5), 489-504.

11 Gudmundsdottir, S., \& Shulman, L. (1987). Pedagogical content knowledge in social studies. Scandinavian Journal of Educationl Research, 31(2), 59-70.

12 Dahlan, M. (2012). Paradigma usul fikih multikultural di Indonesia. ljtihad: Jurnal Wacana Hukum Islam dan Kemanusiaan, 12(1), 1-19; Depaepe, M. (2012). Between educationalization and appropriation: Selected writings on the history of modern educational systems: Leuven University Press; Nugroho, A. (2005). Fikih Kiri: Revitalisasi Usul al-Fiqh untuk Revolusi Sosial. Al-Jami'ah: Journal of Islamic Studies, 43(2), 425-454; Salamah, U. (2017). Teori Pengetahuan Hukum Dalam Ushul Fikih (Kajian Teori Hukum Alam). QISTIE, 10(2).
} 
(1) Apakah ciri-ciri tema kajian berkaitan pengajaran usul figh yang telah dijalankan di Indonesia

(2) Apakah kaedah (model pengajaran yang telah digunakan untuk mengajarakan ilmu usul figh oleh guru-guru usul figh di Indonesia?

(3) Apakah berlaku inovasi dalam pengajaran ilmu usul figh di Indonesia?

\section{Metodologi Penelitian}

Meta-analisis merupakan reka bentuk kajian ini. Kajian berkaitan inovasi pengajaran Imu usul fiqh di Indonesia telah dikaji secara sistematik. Pengenalan ringkas mengenai kajian meta-analisis ialah analisis ke atas analisis yang lain yang melibatkan penggabungan hasil kajian sejenis dengan mengambil kira untuk mendapati kesan yang utama ${ }^{13}$. Bagi membahagikan pemilihan artikel yang sejenis untuk dianalisis, kajian ini menggunakan panduan yang dikemukakan Webster and Watson (2002)14. Bagi mendapatkan data kajian, beberapa pengkalan data telah digunakan untuk mencari artikel berkaitan yang dilanggan oleh perpustakaan university misalnya EBSCOHost, Science Direct, Proquest, dan Sage. Enjine kajian Google Search, Yahoo Search serta Google Scholar turut juga digunakan bagi memastikan carian yang lebih meluas dapat dilakukan. Artikel berkaitan pengajaran usul fiqh yang diterbitkan sekitar tahun 2009 hingga 2018 telah dimuat turun untuk dianalisis. Pengajaran usul fiqh, inovasi pengajaran usul fiqh, Pemakaian ilmu usul fiqh, pengetahuan ilmu usul figh, content usul figh, contemporary ushul fiqh learning telah digunakan sebagai kata kunci yang digunakan untuk mencari artikel yang selari dengan kajian. Antara kriteria pemilihan artikel untuk dianalisa ialah: (i) kajian dalam bidang ilmu usul figh yang menggunakan kerangka teori mengenai pengajaran ilmu

\footnotetext{
13 Zimmerman, R. D., Murillo-Sánchez, C. E., \& Thomas, R. J. (2010). MATPOWER: Steady-state operations, planning, and analysis tools for power systems research and education. IEEE Transactions on power systems, 26(1), 12-19.

14 Webster, J., \& Watson, R. T. (2002). Analyzing the past to prepare for the future: Writing a literature review. MIS quarterly, xiii-xxiii.
} 
usul fiqh; (ii) data kajian dikumpul dalam kalangan pengajar usul fiqh di Indonesia, akhirnya sebanyak 10 artikel kajian inovasi pengajaran ilmu usul figh dikenal pasti memenuhi kriteria yang telah ditetapkan. Jadual 1 menunjukkan senarai artikel berkatan kajian yang dijalankan berkaitan inovasi pengajaran usul figh di Indonesia. Artikel-artikel tersebut telah dianalisis secara sistematik bagi menjawab soalan kajian yang telah ditetapkan.

\section{Jadual 1}

Senarai artikel kajian berkaitan inovasi pengajaran usul figh di Indonesia

\begin{tabular}{|c|c|c|}
\hline Pengkaji (Tahun) & $\begin{array}{l}\text { Jenis } \\
\text { Sampel }\end{array}$ & Jurnal/Prosiding \\
\hline $\begin{array}{l}\text { Roudhlotul Jannah } \\
(2015)\end{array}$ & Umum & $\begin{array}{lll}\text { Prosiding } & \text { Seminar } & \text { Nasional } \\
\text { pendidikan } & & \\
\end{array}$ \\
\hline Nirwan Syafrin (2008) & Umum & Jurnal Tsaqafah \\
\hline $\begin{array}{l}\text { Sapiudin, Abuddin Nata, } \\
\text { \& Usman Syihab (2016) }\end{array}$ & Universiti & Ta`dibuna: Jurnal Pendidikan Islam \\
\hline Rusli (2011) & Umum & Ulul Albab \\
\hline Sapiudin (2014) & Universiti & Ahkam \\
\hline $\begin{array}{l}\text { Abdul Mukti Thabrani } \\
\text { (2011) }\end{array}$ & Umum & Al-Ihkam \\
\hline $\begin{array}{l}\text { Ahmad Ghozali Ihsan } \\
(2018)\end{array}$ & Umum & $\begin{array}{l}\text { Al-Ahkam: Jurnal Ilmu Syari'ah Dan } \\
\text { Hukum }\end{array}$ \\
\hline M. Zainal Anwar (2016) & Universiti & Empirisma \\
\hline Sugeng Aminudin (2016) & Umum & Misykat \\
\hline Nispul Khoiri (2017) & Umum & $\begin{array}{l}\text { IJLRES - International Journal on } \\
\text { Language, Research and Education } \\
\text { studies }\end{array}$ \\
\hline
\end{tabular}


Faisal Bin Husen Ismail, dkk | Hudan Lin Naas, Vol 2, No 1, 2021

\section{Hasil dan Pembahasan}

Dapatan kajian ini dibahagikan kepada tiga Bahagian utama yang akan membicangkan ciri-ciri tema kajian berkaitan inovasi pengajaran usul fiqh yang telah dilakukan di Indonesia. Bahagian ini akan memfokuskan; (i) tema kajian berkaitan keperluan konstruk pembaharuan usul figh, (ii) komponen inovasi usul figh, (iii) topik usul figh yang telah dikaji. Bahagian kedua pula akan membincangkan kaedah yang telah digunakan untuk menjalankan kajian yang telah dilakukan terhadap inovasi pembelajaran usul figh di Indonesia. Bahagian ini akan memfokuskan kepada: (i) jenis dan reka bentuk kajian (metode), (ii) profile sampel kajian dan (iii) instrument yang telah digunakan untuk mengumpul data. Akhir sekali, akan dibincangkan dapatan utama daripada kajian berkaitan inovasi pengajaran usul fiqh di Indonesia.

\section{RQ 1: Apakah ciri-ciri tema kajian inovasi pengajaran usul figh yang telah dijalankan di Indonesia?}

Tema kajian. Berdasarkan analisis kritikal yang telah dijalankan ke atas objektif dan persoalan kajian yang dikemukakan, didapati terdapat 3 tema kajian utama, iaitu (a) mengenal pasti metode pengajaran usul figh, (b) menguji tahap keperluan kontruks ilmu usul fiqh, (c) pemetaan ke atas inovasi ilmu usul figh di Indonesia. Jadual 2 menunjukkan kepada tema-tema yang dikenal pasti daripada kajian lepas. 
Faisal Bin Husen Ismail, dkk | Hudan Lin Naas, Vol 2, No 1, 2021

\section{Jadual 2}

Tema-tema kajian lepas berkaitan metod pengajaran usul fiqh di Indonesia

\begin{tabular}{|c|c|c|}
\hline Tema Kajian & $f$ & Kajian (Tahun) \\
\hline $\begin{array}{l}\text { Mengenal pasti model } \\
\text { pengajaran usul fiqh }\end{array}$ & 3 & $\begin{array}{l}\text { Sapiudin, Abuddin Nata, \& Usman Syihab } \\
\text { (2016); Rusli (2011); Sapiudin (2014) }\end{array}$ \\
\hline $\begin{array}{l}\text { Menguji tahap keperluan } \\
\text { kontruks ilmu usul fiqh }\end{array}$ & 5 & $\begin{array}{l}\text { Nirwan Syafrin (2008); *Rusli (2011), } \\
\text { *Sapiudin (2014); Ahmad Ghozali Ihsan } \\
\text { (2018) }\end{array}$ \\
\hline $\begin{array}{l}\text { Pemetaan ke atas inovasi } \\
\text { ilmu usul fiqh di Indonesia }\end{array}$ & 1 & Nispul Khoiri (2017) \\
\hline
\end{tabular}

*kajian oleh Sapiuddin (2014) dan Rusli (2011) didapati mempunyai dua tema

Berdasarkan analisis yang telah dijalankan, didapati kebanyakan kajian berkaitan inovasi pengajaran ilmu usul fiqh di Indonesia adalah tergolong di bawah tema menguji tahap keperluan konstruk ilmu usul figh di Indonesia. Terdapat lima kajian yang yang telah dijalankan di bawah tema berkenaan. Selain itu, terdapat tiga kajian yang tergolong di bawah tema pengajaran usul figh. Di antara tema pengajaran usul figh adalah pengajaran secara konvensional/tradisional ${ }^{15}$. Antara ciri-ciri pengajaran usul fiqh secara tradisional mempunyai dua ciri-ciri utama iaitu ceramah dan hafazan. ${ }^{16}$

Kontruk ilmu Usul Fiqh. Penganalisaan keperluan konstruk ilmu usul fiqh yang dikaji, didapati terdapat 4 konstruk yang telah difokuskan oleh pengkaji dahulu. Antaranya adalah suasana pembelajaran yang tidak dikaitkan dengan konteks sosial moden, keperluan kepada inovatif pembelajaran, peningkatan kualiti pelajar dan perubahan sikap pelajar, perubahan cara pengajaran ilmu usul fiqh, minat yang lemah

15 Ihsan, A. G. (2018). Pengembangan IImu Ushul Al Fiqh. Al-Ahkam: Jurnal IImu Syari'ah dan Hukum, 2(2), 105-121.

${ }^{16}$ Sapiudin, S. (2014). Pembelajaran ushul Fikih Berbasis Masalah. AHKAM: Jurnal Ilmu Syariah, 14(2); Sapiudin, S., Nata, A., \& Syihab, U. (2016). Model Pembelajaran IImu Ushûl Fiqh di Jurusan Pendidikan Agama Islam (Analisis Penerapan Model Pembelajaran Konvensional dan Pembelajaran Berbasis Masalah). TA'DIBUNA, 5(1), 60-83. 
dikalangan pelajar ilmu usul figh, tuntutan penguasaan ilmu usul fiqh oleh guru, perkaitan diantara ilmu usul figh dengan berfikir kreatif, menjalankan tujuan pendidikan kebangsaan Indonesia. Jadual 3 menunjukkan jenis-jenis konstruk ilmu usul fiqh yang telah dikaji.

\section{Jadual 3}

Kontruks IImu Usul Figh Yang Dikaji

\begin{tabular}{|c|c|c|}
\hline Tema kajian & $f$ & Kajian (Tahun) \\
\hline Implikasi tidak inovatif & 2 & $\begin{array}{l}{ }^{*} \text { Roudhlotul Jannah } \quad \text { (2015); } \quad \text { Sugeng } \\
\text { Aminudin (2016) }\end{array}$ \\
\hline $\begin{array}{l}\text { Keperluan kepada } \\
\text { inovatif }\end{array}$ & 5 & $\begin{array}{l}{ }^{*} \text { Roudhlotul Jannah (2015); }{ }^{* *} \text { Sapiudin, } \\
\text { Abuddin Nata, \& Usman Syihab (2016); } \\
{ }^{* * *} \text { Abdul Mukti Thabrani (2011); }{ }^{* * * *} \text { Ahmad } \\
\text { Ghozali Ihsan (2018); Nispul Khoiri (2017) }\end{array}$ \\
\hline $\begin{array}{l}\text { Pengetahuan kepada } \\
\text { tujuan ilmu usul fiqh }\end{array}$ & 3 & $\begin{array}{l}\text { Nirwan Syafrin (2008); **Sapiudin, Abuddin } \\
\text { Nata, \& Usman Syihab (2016); Sapiudin } \\
\text { (2014) }\end{array}$ \\
\hline $\begin{array}{l}\text { Kaitan inovatif dengan } \\
\text { berfikir kreatif (logik) }\end{array}$ & 3 & $\begin{array}{l}{ }^{*} \text { Roudhlotul Jannah }(2015) ;{ }^{* *} \text { Abdul Mukti } \\
\text { Thabrani }(2011) ;{ }^{* * *} \text { Ahmad Ghozali Ihsan } \\
\text { (2018) }\end{array}$ \\
\hline
\end{tabular}

* Kajian oleh Roudhlotul Jannah (2015), ${ }^{* *}$ Kajian oleh Sapiudin, Abuddin Nata, \& Usman Syihab (2016), ${ }^{* *}$ Kajian oleh Abdul Mukti Thabrani (2011) dan ${ }^{* * * *}$ Kajian oleh Ahmad Ghozali Ihsan (2018) didapati masing-masing mempunyai dua tema.

Berdasarkan analisis yang telah dijalankan, didapati kebanyakan kajian memberikan fokus kepada keperluan inovatif pengajaran ilmu usul figh. Terdapat lima kajian yang telah dijalankan berkaitan inovasi pengajaran ilmu usul figh, manakala sebanyak dua kajian memfokusukan kepada implikasi inovatif pengajaran ilmu usul 
Faisal Bin Husen Ismail, dkk | Hudan Lin Naas, Vol 2, No 1, 2021

fiqh. Masing-masing terdapat tiga kajian yang memfokuskan kepada tujuan pengajaran ilmu usul figh dan kaitan inovatif dengan berfikir kreatif (logik). Dapatan ini menggambarkan terdapat jurang yang lebar di dalam kajian berkaitan konstruk pengajaran ilmu usul figh di Indonesia.

Topik komponen inovasi usul figh. Setelah menganalisis topik komponen pengajaran ilmu usul figh di Indonesia, didapati terdapat 3 topik utama yang telah dikaji. Antaranya topik cara penilaian, metode pembelajaran ilmu usul fiqh, kurikulum pembelajaran. Jadual 4 menunjukkan topik komponen inovasi ilmu usul fiqh yang sering dikaji pengkaji terdahulu.

\section{Jadual 4}

Topik komponen inovasi pengajaran ilmu usul fiqh yang dikaji

\begin{tabular}{|c|c|c|}
\hline Tema kajian & $f$ & Kajian (Tahun) \\
\hline $\begin{array}{ll}\text { Cara } & \text { penilaian } \\
\text { (evaluasi) } & \end{array}$ & 5 & $\begin{array}{l}\text { Sapiudin, Abuddin Nata, \& Usman Syihab } \\
\text { (2016); M. Zainal Anwar (2016). }\end{array}$ \\
\hline $\begin{array}{l}\text { Kurikulum } \\
\text { pembelajaran }\end{array}$ & 1 & Sugeng Aminudin (2016) \\
\hline $\begin{array}{l}\text { Metode pembelajaran } \\
\text { (inovasi) }\end{array}$ & 2 & $\begin{array}{l}\text { Roudhlotul Jannah (2015); Sapiudin, } \\
\text { Abuddin Nata, \& Usman Syihab (2016) }\end{array}$ \\
\hline
\end{tabular}

Berdasarkan analisis yang telah dijalankan, didapati terdapat 5 kajian sahaja yang mengkaji komponen inovasi berkaitan pembelajaran ilmu usul fiqh sepanjang tahun 2009 hingga 2018 di Indonesia. Kebanyakan kajian adalah memfokuskan kepada topik metode pembelajaran. Dapatan topik komponen inovasi meliputi cara penilaian, metode pembelajaran, faktor pemboleh ubah seperti pengenalan asas ilmu usul fiqh kepada pelajar yang bukan dari madrasah pondok, membangun rujukan yang mudah dicapai diperpustakaan dan guru, sifat dorongan keinginan belajar pelajar, mahasisiwa digital mudahkan dengan infografis yang singkat dan padat untuk 
menjelaskan hukum Islam mahupun tokoh-tokoh mazhab dan sebagainya ${ }^{17}$. Manakala komponen evaluasi ke atas hasil pembelajaran ilmu usul fiqh dijalankan secara komprehensif termasuk tes psikometrik (skill) kemampuan individu pelajar dalam mengamalkan kaedah usul figh (tidak mencukupi dengan lisan dan tulisan) tapi juga pada sikap dan amaliah pelajar ${ }^{18}$. Ini memberikan gambaran bahawa kajian berkaitan komponen pengajaran ilmu usul figh di Indonesia seperti metode, cara penilaian, kebolehpakai ilmu usul fiqh dalam kehidupan dan lain-lain adalah kurang diberikan tumpuan oleh pengkaji terdahulu.

$R Q$ 2: Apakah kaedah penyeleidikan yang telah digunakan untuk menjalankan kajian berkaitan inovasi pengajaran ilmu usul fiqh di Indonesia?

Pendekatan dan reka bentuk kajian. Setelah menganalisis kajian berkaitan inovasi pengajaran ilmu usul fiqh yang telah dijalankan di Indonesia, didapati ianya menggunakan pendekatan utama iaitu kualitatif. Manakala dalam konteks reka bentuk kajian pula, didapati ianya terdiri daripada kajian dalam bentuk kajian korelasi, kajian tinjauan. Jadual 5 menunjukkan pendekatan dan reka bentuk kajian yang telah digunakan oleh pengkaji terdahulu berkaitan inovasi pengajaran usul fiqh di Indonesia.

\section{Jadual 5}

Pendekatan dan reka bentuk kajian yang digunakan

\begin{tabular}{llll}
\hline Pendekatan & Reka bentuk & $f$ & \multicolumn{1}{c}{ Kajian (Tahun) } \\
\hline Kualitatif & Kajian kes & 2 & Roudhlotul Jannah (2015); M. Zainal \\
& & & Anwar (2016). \\
& Kajian lapangan & 4 & $\begin{array}{l}\text { Sapiudin, Abuddin Nata, \& Usman } \\
\text { Syihab (2016); Ahmad Ghozali Ihsan }\end{array}$ \\
& & &
\end{tabular}

\footnotetext{
17 Sapiudin, S., Nata, A., \& Syihab, U. (2016). Model Pembelajaran IImu Ushûl Fiqh di Jurusan Pendidikan Agama Islam (Analisis Penerapan Model Pembelajaran Konvensional dan Pembelajaran Berbasis Masalah). Ta'dibuna, 5(1), 60-83.

${ }^{18}$ Anwar, M. Z. (2016). Pengkajian Ushul Fiqh Bagi Pemula di PTKI: Tantangan, Refleksi dan Evaluasi. Empirisma: Jurnal Pemikiran Dan Kebudayaan Islam, 25(2).
} 
Faisal Bin Husen Ismail, dkk | Hudan Lin Naas, Vol 2, No 1, 2021

\begin{tabular}{llll}
\hline & & (2018); Nispul Khoiri (2017); Sugeng \\
& & & Aminudin (2016). \\
\multirow{3}{*}{ Kuantitatif } & Kajian konseptual & 1 & Sapiudin (2014). \\
& Eksperimental & 1 & Rusli (2011). \\
& Deskriptif & 2 & Nirwan Syafrin (2008); Abdul Mukti \\
& & & Thabrani (2011). \\
\hline
\end{tabular}

Berdasarkan analisis yang telah dijalankan, didapati kekerapan kajian menggunakan metode kualitatif dan kuantitatif adalah hamper seimbang. Kebanyakan pengkaji terdahulu telah menggunakan reka bentuk kajian lapangan dalam kajian berkaitan inovasi pengajaran ilmu usul fiqh di Indonesia.

Profil sampel kajian. Seteah menganalisis profil sampel kajian yang dilakuakan pengkaji dahulu berkaitan inovasi pengajaran usul figh di Indonesia, didapati terdapat dua kategori sampel kajian iaitu para pengajar. Sampel tersebut terdiri daripada pengajar di universiti. Jadual 6 menunjukkan maklumat berkaitan profil sampel kajian terdahulu berkaitan inovasi pengajaran usul figh di Indonesia.

\section{Jadual 6}

Profil sampel kajian yang digunakan

\begin{tabular}{llll}
\hline Profil Sampel & \multicolumn{1}{c}{ Jenis } & $\boldsymbol{f}$ & \multicolumn{1}{c}{ Kajian (Tahun) } \\
\hline Pensyarah & Universiti & 6 & Roudhlotul Jannah (2015); \\
& & Sapiudin, Abuddin Nata, \& Usman \\
& & Syihab (2016); Sapiudin (2014); \\
& & Ahmad Ghozali lhsan (2018); M. \\
& & & Zainal Anwar (2016); Sugeng \\
& & & Aminudin (2016). \\
& & 1 & Rusli (2011). \\
Guru & Sekolah Menengah & 1 & Nispul Khoiri (2017). \\
Organisasi & Nahdhatul Ulama, & & \\
& Muhammadiyah dan & &
\end{tabular}




\section{Majelis Ulama \\ Indonesia (NGO \\ Islam)}

Berdasarkan analisis yang telah dijalankan, didapati kebanyakan kajian terdahulu berkaitan inovasi pengajaran ilmu usul figh di Indonesia telah dijalankan dalam kalangan pengajar di peringkat universiti. Profil sampel di atas menjelaskan sebanyak 6 kajian berkaitan inovasi pengajaran usul figh di universiti dan masingmasing satu kajian di sekolah menengah dan oraganisasi bukan kerajaan yang menjadikan usul fiqh juga sebagai salah satu metode dalam mengambil sesuatu masalah berkaitan undang-undang dalam agama Islam. Keadaan ini menunjukkan jurang ketara bagi kajian berkaitan inovasi pengajaran ilmu usul figh di Indonesia dimana institusi pendidikan yang wujud di Indonesia ada pelbagai seperti sekolahsekolah pondok, madrasah-madrasah yang mengajarkan ilmu usul fiqh sebagai subjek yang wajib dipelajari.

Kaedah pengumpulan data. Pengkaji terdahulu telah menggunakan metode pengumpulan data selain daripada reka bentuk dan profil sampel kajiannya. Berdasarkan hasil analisis yang telah dilakukan, didapati terdapat beberapa kaedah yang telah digunakan pengkaji terdahulu. Antara kaedah yang digunapakai adalah ujian, pemerhatian, analisis dokumen. Jadual 7 menunjukkan dapatan kajian terdahulu dengan menggunakan kaedah-kaedah tertentu.

\section{Jadual 7}

Kaedah pengumpulan data yang digunakan

\begin{tabular}{ccc}
\hline Kaedah & $\boldsymbol{f}$ & \multicolumn{1}{c}{ Kajian (Tahun) } \\
\hline Pemerhatian & 7 & Roudhlotul Jannah (2015); Sapiudin, Abuddin \\
& Nata, \& Usman Syihab (2016); Rusli (2011); \\
& Sapiudin (2014); Abdul Mukti Thabrani (2011); \\
& M. Zainal Anwar (2016); Nispul Khoiri (2017).
\end{tabular}


Faisal Bin Husen Ismail, dkk | Hudan Lin Naas, Vol 2, No 1, 2021

\begin{tabular}{lll}
\hline Analisis dokumen 3 & Nirwan Syafrin (2008); Ahmad Ghozali Ihsan \\
& (2018); Sugeng Aminudin (2016)
\end{tabular}

Berdasarkan kepada jadual di atas, kaedah pengumpulan data yang telah dianalisis mendapati kebanyakan kajian terdahulu yang mengkaji inovasi pengajaran ilmu usul fiqh di Indonesia telah menggunakan lebih dari satu kaedah. Kaedah pemerhatian sering digunakan oleh pengkaji terdahulu sebagai metode untuk memperoleh data daripada peserta kajian. Kaedah ini adalah selari dengan dapatan analisis reka bentuk kajian yang telah diguankan iaitu reka bentuk kajian kualitatif kajian kes. Justeru pemerhatian adalah kaedah yang sesuai untuk mengumpul data bagi reka bentuk kajian tersebut.

\section{RQ 3: Apakah dapatan utama daripada kajian berkaitan inovasi pengajaran usul fiqh di Indonesia?}

Dapatan utama kajian inovasi pengajaran ilmu usul fiqh di Indonesia berdarkan objektif kajian yang telah ditetapkan adalah sebagaimana dipaparkan dalam jadual 8 .

\section{Jadual 8}

Dapatan kajian berkaitan inovasi pengajaran ilmu usul figh di Indonesia.

\begin{tabular}{lll}
\hline $\begin{array}{l}\text { Nama Pengkaji dan } \\
\text { Tahun }\end{array}$ & Objektif Kajian & Dapatan Kajian \\
\hline Ahmad Ghozali Ihsan & Untuk mengkaji & Pengajaran inovatif \\
(2018) & hubungan diantara & menyumbang kepada pelajar \\
& inovatif dengan & aktif dan berfikir kreatif. \\
& pengajaran usul fiqh. & Sebaliknya kualiti pelajar usul \\
& & fiqh rendah apabila pengajar \\
& & tidak kreatif dan inovatif dalam \\
& & pengajaran. \\
\hline
\end{tabular}


Faisal Bin Husen Ismail, dkk | Hudan Lin Naas, Vol 2, No 1, 2021

\begin{tabular}{|c|c|c|}
\hline Nispul Khoiri (2017) & $\begin{array}{l}\text { Untuk mengkaji sikap ke } \\
\text { atas mahasiswa serta } \\
\text { mengenalpasti } \\
\text { halangan kepada } \\
\text { pembaharuan inovasi } \\
\text { pengajaran usul fiqh. }\end{array}$ & $\begin{array}{l}\text { Rendahnya minat mempelajari } \\
\text { ilmu usul fiqh dikalangan } \\
\text { mahasiswa. } \\
\text { Politik yang memberi peluang } \\
\text { pengembangan usul fiqh, } \\
\text { Penambahbaikan kelas usul } \\
\text { figh (intelektual, pelajar dan } \\
\text { professional), semanagat } \\
\text { pembentukan masyarakat sivil } \\
\text { serta pengembangan teori } \\
\text { hukum dikenalpasti sebagai } \\
\text { cara mengembangkan ilmu } \\
\text { usul fiqh. }\end{array}$ \\
\hline $\begin{array}{l}\text { M. Zainal Anwar } \\
(2016)\end{array}$ & $\begin{array}{l}\text { Untuk mengemukakan } \\
\text { satu model pembelajran } \\
\text { dan seterusnya } \\
\text { mencadangkan model } \\
\text { bagi pembelajaran } \\
\text { inovatif. } \\
\text { Untuk mengenalpasti } \\
\text { kaedah pengajaran } \\
\text { kepada mahasiswa } \\
\text { yang tidak mempunyai } \\
\text { latar belakang ilmu usul } \\
\text { fiqh di peringkat } \\
\text { universiti. }\end{array}$ & $\begin{array}{l}\text { Pelajar dididik menggunakan } \\
\text { cara dialog seperti } \\
\text { perbincangan mengenai } \\
\text { hukum "bom bunuh diri" } \\
\text { "merokok" "pornografi" } \\
\text { menggunakan ilmu usul figh. } \\
\text { Murid-murid didapati semakin } \\
\text { menghargai perbezaan serta } \\
\text { melakukan aktifiti yang } \\
\text { kooperatif berbanding aktiviti } \\
\text { kompetitif. }\end{array}$ \\
\hline
\end{tabular}




\begin{tabular}{|c|c|c|}
\hline & & kepada mahasiswa yang \\
\hline & & bukan berasal dari madarasah \\
\hline & & mahupun pondok. Begitu juga \\
\hline & & motivasi dan rangsangan \\
\hline & & untuk mempelajari ilmu usul \\
\hline & & figh amat kurang diberikan. \\
\hline & & Penggunaan bahan bantu \\
\hline & & mengajar di era digital juga \\
\hline & & kurang dimanfaatkan oleh \\
\hline & & pengajar. \\
\hline Sugeng Aminudin & Untuk menyiasat tahap & Kajian mendapati kurangnya \\
\hline (2016) & penguasaan pendidik & penguasaan dan penggunaan \\
\hline & ilmu usul fiqh. & kemudahan ict dikalangan \\
\hline & & pendidik. \\
\hline & Untuk mengenalpasti & Kajian juga mendapati \\
\hline & samaada kurikulum & penggunaan kurikulum yang \\
\hline & yang digunakan & kurang inovatif turut \\
\hline & menepati sasaran di & mengakibatkan rendahnya \\
\hline & Indonesia. & minat pelajar. \\
\hline & & Kajian juga mendapati \\
\hline & & kurikulum yang ada tidak \\
\hline & & emnepati sepenuhnya \\
\hline & & kehendak pendidikan \\
\hline & & diperingkat kebangsaan. \\
\hline Sapiudin, Abuddin & Untuk meneroka & Kajian mendapati pengajaran \\
\hline Nata, \& Usman & keperluan pembelajaran & ilmu usul fiqh berorientasikan \\
\hline Syihab (2016) & inovatif ilmu usul figh. & teacher center. \\
\hline
\end{tabular}




$\begin{array}{ll}\begin{array}{ll}\text { Untuk mengkaji } \\ \text { perkaitan pembangunan }\end{array} & \begin{array}{l}\text { Penkaji menghendaki } \\ \text { wujudnya tindakan }\end{array} \\ \begin{array}{ll}\text { Ilmu usul fiqh dengan } \\ \text { logik berfikir. }\end{array} & \begin{array}{l}\text { pembaharuan di madrasah } \\ \text { dan universiti memperbetulkan } \\ \text { sikap ke atas pembelajaran }\end{array} \\ \begin{array}{ll}\text { Untuk mengenalpasti } \\ \text { kaedah membangun }\end{array} & \begin{array}{l}\text { ilmu usul fiqh. } \\ \text { ilmu usul fiqh di }\end{array} \\ \begin{array}{ll}\text { Indonesia. } & \text { Selain itu, kajian mendapati } \\ & \text { pembelajaran secara } \\ \text { tradisional tidak mengaitkan } \\ \text { dengan konteks keadaan }\end{array} \\ & \text { semasa. }\end{array}$

Kajian mendapati kaitan rapat diantara ilmu usul figh dengan metode berfikir logik yang diiktiraf agama.

Kajian mencadangkan contoh kaedah bagi membangun ilmu usul fiqh di Indonesia.

Roudhlotul Jannah (2015)

Untuk mengkaji
penyediaan pedagogi
ilmu usul figh di
universiti.

Kajian mencadangkan beberapa jenis pedagogi persediaan mengajar kepada pelajar.

Pengkaji menghendaki wujudnya usaha berterusan 


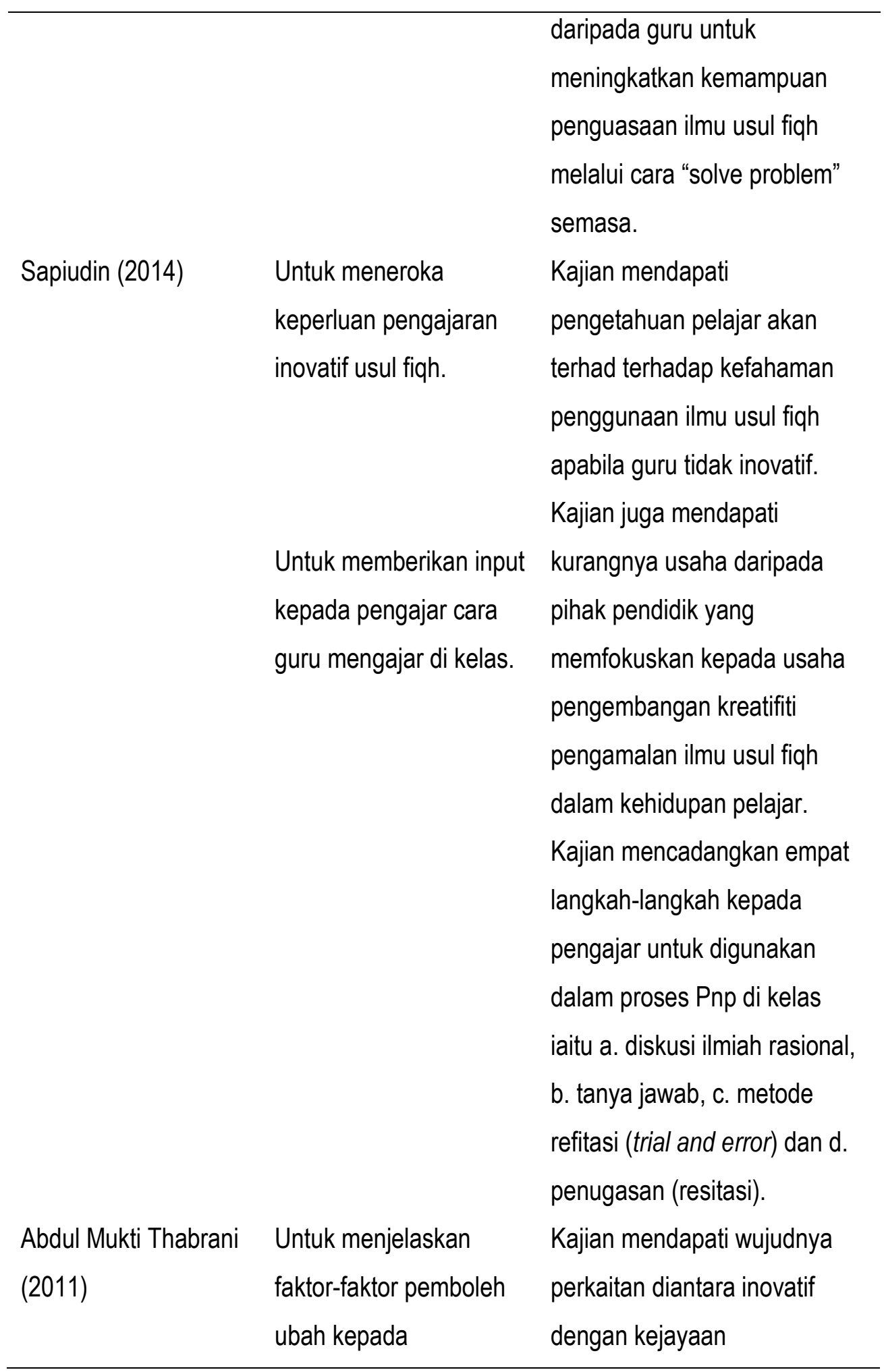


Faisal Bin Husen Ismail, dkk | Hudan Lin Naas, Vol 2, No 1, 2021

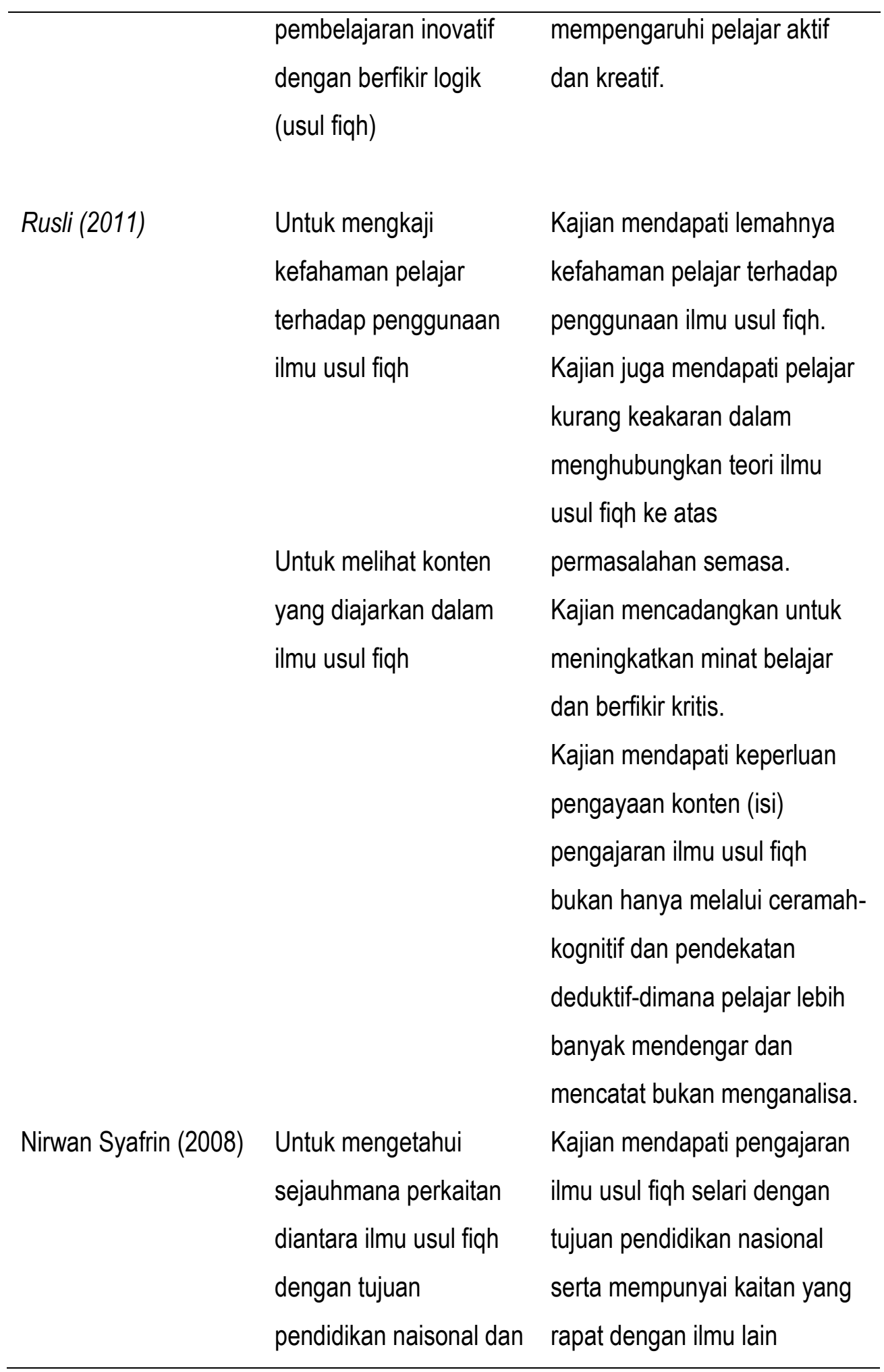


Faisal Bin Husen Ismail, dkk | Hudan Lin Naas, Vol 2, No 1, 2021

$$
\begin{array}{ll}
\text { ilmu-ilmu lain yang } & \text { misalnya teologi dan filsafat, } \\
\text { berkaitan dengannya. } & \begin{array}{l}
\text { ilmu mantiq mahupun ilmu } \\
\text { kalam. }
\end{array}
\end{array}
$$

Berdasarkan penganalisaan yang dilakukan ke atas dapatan utama kajian inovasi pengajaran usul fiqh di Indonesia, didapati ianya boleh dibahagi kepada beberapa tema. Pertama; bagi tema inovasi pengajaran ilmu usul figh, didapati lemahnya inovasi pengajaran ilmu usul figh dimana model pengajaran banyak dijalankan secara tradisional serta bertumpu kepada guru (Aminudin, 2018)19. Begitu juga tema berkaitan tahap kefahaman pelajar ke atas penggunaan ilmu usul fiqh, didapati kefahaman pelajar adalah pada tahap sederhana dan rendah (Ihsan, 2018; Rusli, 2013)20. Natijah kelemahan pelajar turut dipengaruhi oleh faktor lemahnya inovasi pengajaran. Perkara ini selari sebagaimana kajian yang dilakukan Thabrani $(2013)^{21}$. Kedua, bagi tema kesan pengajaran inovatif dalam pengajaran usul fiqh dengan pemboleh ubah-pemboleh ubah lain, didapati terdapat hubungan signifikan diantara pengajaran inovatif kepada pelajar berfikir aktif dan kreatif22 dan konten pengajaran ${ }^{23}$ dan proses pengajaran dan pembelajaran di kelas, pembangunan kreatifiti pengajaran ${ }^{24}$, dan penyediaan pedagogi pengajaran usul figh ${ }^{25}$. Ketiga, bagi

\footnotetext{
${ }^{19}$ Aminudin, S. (2018). Standarisasi Kurikulum Ushul Fiqh. MISYKAT: Jurnal IImu-ilmu Al-Quran, Hadist, Syari'ah dan Tarbiyah, 1(2), 139.

20 Ihsan, A. G. (2018). Pengembangan IImu Ushul Al Figh. Al-Ahkam: Jurnal IImu Syari'ah dan Hukum, 2(2), 105-121; Rusli, R. (2013). Pedagogi Usul Al Fiqh Berbasis Pendidikan Perdamaian Di Era Multikultural. ULUL ALBAB Jurnal Studi Islam, 12(2), 139-156.

21 Thabrani, A. M. (2013). Pengembangan Fiqh al-'Ilmiyah Melalui Pendekatan Mashlahah dan Tajdid. AL-IHKAM: Jurnal Hukum \& Pranata Sosial, 6(2), 184-200.

22 Sapiudin, S., Nata, A., \& Syihab, U. (2016). Model Pembelajaran IImu Ushûl Fiqh di Jurusan Pendidikan Agama Islam (Analisis Penerapan Model Pembelajaran Konvensional dan Pembelajaran Berbasis Masalah). TA'DIBUNA, 5(1), 60-83.

${ }^{23}$ Rusli, R. (2013). Pedagogi Usul Al Figh Berbasis Pendidikan Perdamaian Di Era Multikultural. ULUL ALBAB Jurnal Studi Islam, 12(2), 139-156.

24 Sapiudin, S. (2014). Pembelajaran ushul Fikih Berbasis Masalah. AHKAM: Jurnal IImu Syariah, 14(2).

25 Jannah, R. (2019). Internalisasi Paradigma Ushul Fiqh Melalui Pembelajaran Inovatif. Paper presented at the Seminar Nasional Pendidikan 2015.
} 
menjelaskan konten yang diajarkan dalam pengajaran ilmu usul fiqh di Indonesia, didapati pengajar telah menggunakan pendekatan secara kognitif melalui ceramah namun juga menggunakan pendekatan deduktif dimana pelajar lebih banyak mendengar dan mencatat bukan menganalisa. ${ }^{26}$ Selain itu penggunaan bentuk dan model pengajaran turut mempengaruhi kefahaman murid berkaitan penggunaan ilmu usul figh. ${ }^{27}$

\section{KESIMPULAN}

Inovasi pengajaran ilmu usul figh berperanan memastikan pengajaran dan pembelajaran yang berkesan dan seterusnya mampu meningkatkan penguasaan dan penggunaan ilmu usul fiqh dalam memastikan undang-undang Islam serta seluruh ajarannya relevan dengan perkembangan zaman ${ }^{28}$. Kelemahan inovasi dalam pengajaran kepada pelajar-pelajar di peringkat universiti secara tidak langsung memberi kesan kepada proses pengajaran dan pembelajaran serta pengaplikasian usul fiqh yang kurang berkesan ${ }^{29}$. Daripada analisis yang telah dijalankan, didapati konten pengajaran usul figh masih lagi menggunakan contoh-contoh lama dalam pengajaran. Selain itu, pengkaji lepas banyak memberikan tumpuan kepada keperluan pembaharuan ilmu usul figh sahaja. Kajian yang dijalankan berkaitan dengan pemboleh-pemboleh ubah dengan inovasi pembelajaran usul fiqh didapati sekedar menjelaskan sama ada terdapat kaitan rapat ataupun tidak dengan pembolehpemboleh ubah tersebut. Tidak terdapat sebarang kajian yang menjelaskan pengaruh

\footnotetext{
${ }^{26}$ Anwar, M. Z. (2016). Pengkajian Ushul Fiqh Bagi Pemula di PTKI: Tantangan, Refleksi dan Evaluasi. Empirisma: Jurnal Pemikiran Dan Kebudayaan Islam, 25(2).

27 Khoiri, N. (2017). The Mapping of Renewal of 'Usul Fiqh'Thoughts In Indonesia. International Journal on Language, Research and Education Studies, 1(1), 18-33.

$28 \mathrm{Goos}$, M. (2013). Knowledge for teaching secondary school mathematics: what counts? International Journal of Mathematical Education in Science and Technology, 44(7), 972-983; Zarkasyi, A. F. (2013). Tajdid dan Modernisasi Pemikiran Islam. TSAQAFAH, 9(2), 395-418.

${ }^{29}$ Arifin, S. (2019). Model Pembelajaran Ushul Fiqih Berdimenasi Soft Skils. Jurnal Tatsqif, 17(2), $11-$ 29; Hussin, N. (2017). Penggunaan laman web sebagai transformasi dalam pengajaran dan pembelajaran pendidikan Islam. O-JIE: Online Journal of Islamic Education, 1(2).
} 
pemboleh-pemboleh ubah tersebut ke atas prestasi pelajar dan terhadap penguasaan pengajar usul fiqh.

Justeru, dicadangkan kajian pada masa hadapan dapat memberi fokus pada membandingkan dan menguji pemboleh-pemboleh ubah kognitif yang mengubah perilaku pembelajaran dan pengajaran inovatif usul fiqh dalam konteks penguasaan ilmu figh di Indonesia. Secara keseluruhan, kajian telah menghasilkan pengetahuan baru berkaitan inovasi pengajaran ilmu usul fiqh di Indonesia.

\section{ACKNOWLEDGMENT}

This research has been carried out under Research Fund E15501, Research Management Centre, University Tun Hussein Onn Malaysia.

\section{Daftar Pustaka}

Abdul Karim, M. A. (2013). Pola Pemikiran Imam Syafi'i dalam Menetapkan Hukum Islam. Jurnal Adabiyah Vol. XIII nomor, 187. http://journal.uinalauddin.ac.id/index.php/adabiyah/article/view/269

Aminudin, S. (2018). Standarisasi Kurikulum Ushul Fiqh. MISYKAT: Jurnal IImu-ilmu Al-Quran, Hadist, Syariah dan Tarbiyah, 1(2), 139. http://dx.doi.org/10.33511/misykat.v1n2.139

Anwar, M. Z. (2016). Pengkajian Ushul Figh Bagi Pemula di PTKI: Tantangan, Refleksi dan Evaluasi. EMPIRISMA: JURNAL PEMIKIRAN DAN KEBUDAYAAN ISLAM, 25(2). https://doi.org/10.30762/empirisma.v25i2.180

Arifin, S. (2019). Model Pembelajaran Ushul Fiqih Berdimenasi Soft Skils. Jurnal Tatsqif, 17(2), 11-29. https://doi.org/10.20414/jtq.v17i2.974

Baumert, J., Kunter, M., Blum, W., Brunner, M., Voss, T., Jordan, A., . . Tsai, Y.-M. (2010). Teachers' mathematical knowledge, cognitive activation in the classroom, and student progress. American educational research journal, 47(1), 133-180. https://doi.org/10.3102/0002831209345157

Dahlan, M. (2012). Paradigma usul fikih multikultural di Indonesia. Ijtihad: Jurnal Wacana Hukum Islam dan Kemanusiaan, 12(1), 1-19. https://doi.org/10.18326/ijtihad.v12i1.1-19

Depaepe, M. (2012). Between educationalization and appropriation: Selected writings on the history of modern educational systems: Leuven University Press.

Fung, D., Kutnick, P., Mok, I., Leung, F., Lee, B. P.-Y., Mai, Y. Y., \& Tyler, M. T. (2017). Relationships between teachers' background, their subject knowledge and pedagogic efficacy, and pupil achievement in primary school mathematics in 
Hong Kong: An indicative study. International Journal of Educational Research, 81, 119-130. https://doi.org/10.1016/i.jier.2016.11.003

Goos, M. (2013). Knowledge for teaching secondary school mathematics: what counts? International Journal of Mathematical Education in Science and Technology, 44(7), 972-983. https://doi.org/10.1080/0020739X.2013.826387

Gudmundsdottir, S., \& Shulman, L. (1987). Pedagogical content knowledge in social studies. Scandinavian Journal of Educationl Research, 31(2), 59-70. https://doi.org/10.1080/0031383870310201

Hussin, N. (2017). Penggunaan laman web sebagai transformasi dalam pengajaran dan pembelajaran pendidikan Islam. O-JIE: Online Journal of Islamic Education, 1(2). https://ojie.um.edu.my/article/view/5534

Ihsan, A. G. (2018). Pengembangan IImu Ushul Al Figh. Al-Ahkam: Jurnal IImu Syari'ah dan Hukum, 2(2), 105-121. http://dx.doi.org/10.22515/alahkam.v2i2.1069

llyas, H. H., \& Ag, M. (2018). Fikih Akbar: Prinsip-Prinsip Teologis Islam Rahmatan Lil 'Alamin: Pustaka Alvabet.

Jannah, R. (2019). Internalisasi Paradigma Ushul Fiqh Melalui Pembelajaran Inovatif. Paper presented at the Seminar Nasional Pendidikan 2015. http://seminar.umpo.ac.id/index.php/semnasdik2015/article/viewFile/223/224.

Johari, K., Ismail, Z., Osman, S., \& Othman, A. T. (2009). Pengaruh Jenis Latihan Guru dan Pengalaman Mengajar Terhadap Efikasi Guru Sekolah Menengah (The Influence of Teacher Training and Teaching Experience on Secondary School Teacher Efficacy). Jurnal Pendidikan Malaysia (Malaysian Journal of Education), 34(2), 3-14. http://pkukmweb.ukm.my/ -jurfpend/index.html

Khoiri, N. (2017). The Mapping Of Renewal Of 'Usul Figh'Thoughts In Indonesia. International Journal on Language, Research and Education Studies, 1(1), 1833. http://jurnal.uinsu.ac.id/index.php/ijlres/article/view/939

Kilpatrick, J., Swafford, J., \& Findel, G. (2001). Teaching for mathematical proficiency. Adding it up: Helping children learn mathematics, 313-368. DOI $10.17226 / 9822$

Kunter, M., Klusmann, U., Baumert, J., Richter, D., Voss, T., \& Hachfeld, A. (2013). Professional competence of teachers: Effects on instructional quality and student development. Journal of Educational Psychology, 105(3), 805. DOI: $10.1037 / \mathrm{a} 0032583$

Luetz, J. M., Margus, R., \& Prickett, B. (2019). Human Behavior Change for Sustainable Development: Perspectives Informed by Psychology and Neuroscience. In W. Leal Filho, A. M. Azul, L. Brandli, P. G. Özuyar, \& T. Wall (Eds.), Quality Education (pp. 1-16). Cham: Springer International Publishing. Nugroho, A. (2005). Fikih Kiri: Revitalisasi Usul al-Figh untuk Revolusi Sosial. AlJami'ah: Journal of Islamic Studies, 43(2), $425-454$. https://doi.org/10.14421/ajis.2005.432.425-454 
Qutb, S. M. (1992). Petunjuk Sepanjang Jalan. Kuala Lumpur: Crescent News Sdn. Bhd.

Rusli, R. (2013). Pedagogi Usul Al Figh Berbasis Pendidikan Perdamaian Di Era Multikultural. ULUL ALBAB Jurnal Studi Islam, 12(2), 139-156. http://dx.doi.org/10.18860/ua.v0i0.2387

Salamah, U. (2017). Teori Pengetahuan Hukum Dalam Ushul Fikih (Kajian Teori Hukum Alam). QISTIE, 10(2). http://dx. doi.org/10.31942/jgi.v10i2.2075

Sapiudin, S. (2014). Pembelajaran ushul Fikih Berbasis Masalah. AHKAM: Jurnal IImu Syariah, 14(2). DOI: $10.15408 / a j i s . v 14 i 2.1288$

Sapiudin, S., Nata, A., \& Syihab, U. (2016). Model Pembelajaran Ilmu Ushûl Fiqh di Jurusan Pendidikan Agama Islam (Analisis Penerapan Model Pembelajaran Konvensional dan Pembelajaran Berbasis Masalah). TA'DIBUNA, 5(1), 60-83. http://dx.doi.org/10.32832/tadibuna.v5i1.571

Segall, A. (2004). Revisiting pedagogical content knowledge: the pedagogy of content/the content of pedagogy. Teaching and teacher education, 20(5), 489504. DOI: $10.1016 /$ j.tate.2004.04.006

Suartama, I. K. (2010). Pengembangan mutimedia untuk meningkatkan kualitas pembelajaran pada mata kuliah media pembelajaran. Jurnal Pendidikan dan Pengajaran, 43(3). http://dx.doi.org/10.23887/jppundiksha.v43i3.130

Thabrani, A. M. (2013). Pengembangan Fiqh al-'Ilmiyah Melalui Pendekatan Mashlahah dan Tajdid. AL-IHKAM: Jurnal Hukum \& Pranata Sosial, 6(2), 184200. ejournal.stainpamekasan.ac.id

Webster, J., \& Watson, R. T. (2002). Analyzing the past to prepare for the future: Writing a literature review. MIS quarterly, xiii-xxiii. DOI: $10.2307 / 4132319$

Zarkasyi, A. F. (2013). Tajdid dan Modernisasi Pemikiran Islam. TSAQAFAH, 9(2), 395-418. http://dx.doi.org/10.21111/tsaqafah.v9i2.59

Zimmerman, R. D., Murillo-Sánchez, C. E., \& Thomas, R. J. (2010). MATPOWER: Steady-state operations, planning, and analysis tools for power systems research and education. IEEE Transactions on power systems, 26(1), 12-19. DOI: 10.1109/TPWRS.2010.2051168 